\title{
MODEL MENINGKATKAN NIAT BELI PRODUK HIJAU: SEBUAH PENDEKATAN STRATEGIK
}

\author{
Jati Waskito \\ Banu Witono \\ Fakultas Ekonomi dan Bisnis Universitas Muhammadyah \\ jati.waskito@ums.ac.id
}

\begin{abstract}
This study aims to develop the results of previous research, as follows: 1) design and test a model of consumer perceptions (that has been mapped during year-1 of a comprehensive review of the eco-friendly products 2) analyze the factors (i.e. environmentally friendly corporate image, perceptions of environmentally friendly products, product labels, and government regulations) that influence purchasing decisions of eco-friendly products based on design and test result on the proposed model 3) identify the most important factors considered by the consumers through comprehensive model testing, so as to provide empirical evidence for the sake of implementing environmentally conscious marketing strategy.The results of the field survey managed to get 293 respondents who are willing to participate. The conclusions of the study are 1) the proposed research model in this study is able to represent a comprehensive picture of people's perception on environmentally friendly products; 2) regulatory, corporate image, and product perceptions variables significantly shape the public perception of the eco-friendly products; 3) corporate image variable is the most important element in shaping public perceptions on environmentally friendly products.
\end{abstract}

Keywords: environmental, green product, marketing strategic

\section{LATAR BELAKANG}

Kesadaran masyarakat terhadap lingkungan berdampak pada kecenderunganperusahaan untuk lebih peduli terhadap perlindungan lingkungan sebagaitanggung jawab sosial mereka (Dwyer 2009; Lee et al., 2011).Merespon peningkatan kepedulian masyarakat terhadap lingkungan ini, banyak perusahaan yang berpikir keras untuk dapat memanfaatkan peluang isu ini demi kepentingan bisnis mereka(Haden et al., 2009).Dalam era yang semakin sadar dengan kelestarian lingkungan,perusahaan mulai lebih memperhatikan pemasaran hijau (green marketing) di beberapa industri, sepertiindustri informasi dan elektronik (Chen 2010).Kesadaran terhadap lingkungan tidak hanya membantu organisasi untuk tetap 
kompetitif dan meningkatkan pangsa pasar (Chan 2001) tetapi juga ada beberapa bukti menunjukkan adanya peningkatan loyalitas pelanggan.

Hasil penelitian Waskito dan Harsono (2012) menemukan bahwa konsumen mempunyai tingkat kesadaran yang tumbuh pada produk ramah lingkungan. Namun demikian hasil penelitian tersebut menunjukkan bahwa tumbuhnya tingkat kesadaran tersebut belum disertai dengan action atau keputusan pembelian produk hijau. Menindaklanjuti temuan ini, dengan menggunakan daerah penelitian yang sama (warga kota Joglosemar), studi ini akan lebih terfokus pada persepsi masyarakat terhadap produk ramah lingkungan. Pengetahuan secara komprehensif mengenai hal ini, akan sangat membantu bagi pelaku bisnis untuk menyusun dan mengimplementasikan strategi pemasaran mereka dengan memasukkan unsur kepedulian terhadap lingkungan.

Studi ini meneliti informasi yang lebih komprehensif tentang persepsi masyarakat terhadap produk ramah lingkungan dengan menjawab beberapa pertanyaan berikut ini: 1) bagaimana model persepsi konsumen secara komprehensif terhadap produk ramah lingkungan? 2) Faktor-faktor apa saja (yaitu citra perusahaan yang ramah lingkungan, persepsi terhadap produk ramah lingkungan, label produk dan peraturan pemerintah) yang berpengaruh terhadap keputusan pembelian produk ramah lingkungan berdasarkan hasil rancangan dan pengujian pada model yang diusulkan (poin 1)? 3) Apakah yang dianggap sebagai faktor terpenting oleh konsumen melalui pengujian model secara komprehensif pada poin 2, sehingga dapat memberikan bukti empiris untuk kepentingan implementasi strategi pemasaran berwawasan lingkungan?

\section{STUDI PUSTAKA DAN HIPOTESIS}

\section{Persepsi Korporat (Citra Perusahaan)}

Bencana yang bermunculan sebagai dampak dari buruknya kondisi lingkungan akhir-akhir ini, semakin menyadarkan kita akan arti pentingnya isu lingkungan natural untuk diperhitungkan semua pihak, terutama perusahaan. Aktivitas bisnis, diakui atau tidak, telah memberikan sumbangan yang signifikan terhadap menurunnya kualitas lingkungan alam. Saat ini masyarakat semakin menyadari isu-isu lingkungan karena seringnya terjadi bencana sebagai akibat daripencemaran lingkungan yang muncul dari kegiatan industri manufaktur di dunia (Chen 2011).Hasil penelitian Waskito dan Harsono (2012) menemukan mulai tumbuhnya tingkat kesadaran masyarakat terhadap pelestarian lingkungan dan ketertarikan terhadap produk ramah lingkungan.

Masalah perlindungan lingkungan tidak lagi menjadi isu perdebatan dan kini diakui dan diterima menjadi strategi perusahaan-perusahaan multinasional yang paling kompetitif dan sukses. Sebagai tindak lanjut pada sikap konsumen untuk 
menjaga lingkungan telah membuat produk "ramah lingkungan" menjadi isu penting bagi para manajer dan pemasar. Namun, perhatian dasar bagi sebagian besar bisnis lebih merupakan upaya untuk mengelola sumber daya perusahaan terhadap dampak lingkungan secara efektif dan efisien, daripada restrukturisasi bisnis dan penawaran pasar mereka di sekitar isu-isu keamanan lingkungan. Bagi banyak perusahaan, tantangannya adalah untuk menyeimbangkan kepedulian konsumen mereka terhadap lingkungan hidup dengan arus kas, profitabilitas (Berry dan Rondinelli 1998) dan pendekatan strategis perusahaan berkelanjutan dengan intensitas persaingan di pasar sasaran tertentu.

Mulai tumbuhnya kesadaran ini berdampak pada kecenderunganperusahaan untuk lebih peduli terhadap perlindungan lingkungan sebagaitanggung jawab sosial mereka (Dwyer 2009; Lee 2009).Merespon peningkatan kepedulian masyarakat terhadap lingkungan ini, banyak perusahaan yang berpikir keras untuk dapat memanfaatkan peluang isu ini demi kepentingan bisnis mereka(Haden et al., 2009).Dalam era yang semakin sadar dengan kelestarian lingkungan,perusahaan mulai lebih memperhatikan pemasaran hijau (green marketing) di beberapa industri, sepertiindustri informasi dan elektronik (Chen 2010).

\section{Peraturan Lingkungan}

Peraturan lingkungan telah memberikan parameter yang jelas pada tingkat yang dapat diterima secara hukum dari tanggung jawab dan akuntabilitas perusahaan. Pada saat yang sama, dalam mengantisipasi harapan pasar sasaran mereka, perusahaan telah merumuskan dan menerapkan strategi secara hati-hati sehubungan dengan perilaku bisnis yang aman dengan memperhatikan lingkungan. Bisnis telah secara aktif menciptakan dan menunjukkan citra perusahaan berorientasi lingkungan.

Semakin gencarnya tekanan publik dan peraturan pemerintah, menjadi keharusan bagi perusahaan untuk memperhatikan masalah lingkungan dan memastikan bahwa proses yang dilakukan dan produk yang dihasilkan oleh perusahaan memenuhi standar keamanan bagi lingkungan hidup (Bonini et al., 2008).Berkaitan dengan regulasi lingkungan hidup tersebut, dapat dimengerti bahwa kompetensi dan kemampuan kunci perusahaan, dapat menjadi penghambat untuk memanfaatkan kompetensi lingkungan (Rugman dan Verbeke 1998). Selain itu, kepatuhan terhadap regulasi adalah tidak murah. Oleh karena itu, melanggar atau tidak patuh terhadap peraturan lingkungan tidak dapat dihindari dan perusahaan mengharapkan untuk dapat menghindari kepatuhan bila memungkinkan. Pemerintah diharapkan untuk menerapkan hukuman yang cukup berat sehingga dapat memaksa perusahaan mematuhi peraturan (Lyon 2003).

Namun, di sisi lain, melalui tingkat kepatuhan perusahaan yang tinggiterhadap peraturan cenderung untuk menempatkan diri mereka melalui pengakuan yang lebih kuat di masyarakat dan nilai pelanggan yang lebih tinggi (Arora dan Cason1996). Pada saat yang sama, mengamati dan mendemonstrasikan 
kepatuhan terhadap regulasi lingkungan hidup dan berusaha melampaui persyaratan peraturan untuk kepentingan konsumen dapat dianggap sebagai keunggulan kompetitif (Russo dan Fouts 1997). Dapatkah perusahaan yang menunjukkan tingkat kepatuhan ramah lingkungan, berpengaruh terhadap niat pembelian konsumen untuk membeli merek ramah lingkungan?

\section{Persepsi Harga dan kualitas}

Pemahaman yang umum keliru sertasulit untuk diperhitungkan adalah trade off dalam atribut yang digunakan konsumen ketika membuat pilihan. Teori persepsi risiko menyatakan bahwa konsumen tertarik untuk meminimalkan risiko yang merekarasakan dan bukan untuk memaksimalkan utilitas mereka.Asimetri informasimembuatnya lebih sulit bagi pembeli untuk mengidentifikasi performa produk yang sebenarnya sebelum melakukan pembelian(Chen dan Chang 2012).Kondisi ini memberikan insentif bagi penjual untuk bertindakjujur.Akhirnya, para pembeli tidak mau membeliproduk karena ketidakpercayaan mereka dari penjual yang disebabkan oleh asimetri informasiantara pembeli dan penjual (Gregg dan Walczak 2008).Konsumen telah menunjukkan kesediaan untuk menanggapi kekhawatiran ramah lingkungan tetapi mereka tidak mau kompromi dengan performa, kenyamanan dan harga (Eid 2011). Bahkan ketika para peneliti secara eksplisit telah mempertimbangkan perilaku pembelian aktual konsumen, perilaku ini melibatkan faktor-faktor di luar status ekologi merek tertentu(Henion 1972). Sementara itu, fitur lingkungan dapat meningkatkan keinginan untuk memiliki produk tersebut, kriteria pilihan yang terpenting adalah kemanfaatan. Apakah persepsi konsumen pada harga yang lebih tinggi dan kualitas rendah dapat mempengaruhi perilaku pembelian produk ramah lingkungan?

\section{Dimensi-Dimensi Produk}

Jika konsumen punya keniatan untuk membeli produk ramah lingkungan maka keputusan pembelian di sini dibuat tidak hanya pada produk ramah lingkungan itu sendiri, yang memberikan manfaat utama bagi konsumen saja, tetapi juga manfaat sosial lainnya. Misalnya, konsumen akan merasakan bahwa tindakannya membeli produk ramah lingkungan akan dapat menjadikan lingkungan mereka aman. Masalahnya di sini terletak dalam memahami manfaat ganda bagi merek produk ramah lingkungan.Pertama, kinerja fungsionalnya dan yang kedua aspek keselamatan lingkungannya.

Namun demikian, persepsi nilai dari suatu produk dapat berbeda untuk konsumen yang berbeda dan dapat disampaikan pada tingkat yang berbeda. Adcock (2000), mengkategorikan produk ke dalam tiga tingkatan: 1) tingkat dasar nilai yang diharapkan yang sesuai dengan manfaat produk yang diharapkan konsumen; 2) tingkat nilai yang konsumen menginginkannya dan akhirnya, 3) nilai yang tak terduga, yang melebihi harapan pelanggan. Idealnya, dalam situasi seperti ini untuk konsumen ramah lingkungan mereka akan bersandar untuk melakukan penelitian 
lebih ke arah produk-produk ramah lingkungan dari sudut pandang kemasan mereka sebagaimana dari apa bahan sebuah produk.

Literatur merefleksikan kepedulian konsumen untuk produk-produk yang diuji pada binatang dan mereka yang berpotensi membahayakan satwa liar. Keprihatinan ini dominan dalam produk-produk kosmetik, di mana klaim keselamatan telah menjadi salah satu strategi pemasaran baik dalam pengembangan produk dan strategi pemasaran diferensiasi yang disampaikan kepada pengguna akhir. Walaupun masalah ini tidak dapat diklasifikasikan sebagai bagian dari produk keamanan lingkungan, akan tetapi tetap berorientasi lingkungan dan akan menjadi faktor dalam keputusan pembelian pelanggan.

Di sisi lain, tampilan kemasan produk konsumen yang spesifik terlihat unsur kepedulian lingkungan bagi pelanggan. Pembuangan kemasan produk, bahan yang digunakan dan biaya yang terkait dengan kemasan bahan yang berlebihan menawarkan campuran pengingat bahwa bisnis kadang-kadang menggunakan kemasan diluar fungsi kegunaan produk tersebut, sehingga hal merugikan keamanan lingkungan dan kepedulian bagi bahan yang tidak dapat didaur ulang. Bahan yang dapat didaur ulang sampai batas tertentu dapat merupakan alasan pembenaran penggunaannya dan klaim penggunaan bahan ini secara keseluruhan dapat meminimumkan dampak kerusakan terhadap lingkungan.

Pada dasarnya, konsumen memperkirakan nilai komparatif ketika mereka membuat referensi untuk beberapa ukuran utilitas yang mereka terima dari produk ramah lingkungan. Dimensi sosial, seperti daur ulang, biodegradable dan penghematan energi yang faktor-faktor non-utilitas dipertimbangkan ketika menaksir nilai merek ramah lingkungan. Dapatkah persepsi konsumen berdasarkan faktorfaktor ini mendorong niat untuk membeli produk ramah lingkungan?

\section{Label-Label Produk}

Pelabelan pada produk lingkungan adalah cara yang efektif untuk mengkomunikasikan kepada pelanggan manfaat spesifik dan karakteristik produk dan klaim keselamatan. Informasi ini disediakan pada tahap penting pengambilan keputusan pelanggan. Label lingkungan dapat ditampilkan menggunakan simbolsimbol atau pesan yang aman lingkungan. Tujuan utama mereka selain untuk menginformasikan kepada pelanggan karakteristik keamanan dari produk ini adalah untuk membantu perusahaan memposisikan diri sebagai organisasi peduli lingkungan. Kedua, tujuan label lingkungan adalah untuk memproyeksikan gambar ramah lingkungan, gambar ramah lingkungan ini juga melampaui ke foto reputasi lingkungan perusahaan dengan menjadi "sensitif lingkungan" untuk kelompok stakeholder. Terutama untuk pertama kalinya pembeli, label lingkungan berdiri sebagai kriteria untuk membuat suatu pilihan awal dalam melakukan pembelian.

Para ahli komunikasi pemasaran melibatkan transmisi tanda-tanda, kode dan simbol-simbol yang terus-menerus diterjemahkan oleh konsumen sehingga dapat 
membuat keputusan pembelian dan merenungkan pilihan ini di dalam pola pikir mereka, tanda-tanda yang berlaku umum, kode dan simbol harus dipopulerkan dan dipublikasikan untuk membantu komunikasi pesan pada produk aman lingkungan. Hal ini diantisipasi bahwa label lingkungan, berpotensi, memprovokasi dan memodifikasi perilaku pembelian, sebagai konsumen yang bersedia untuk mencari informasi tentang produk lingkungan dan untuk membaca label produk untuk informasi pengambilan keputusan yang lebih baik (Carlson et al., 1993).

Pelanggan juga secara aktif mencari informasi keamanan lingkungan label produk. Namun, yang menarik, konsumen juga mengungkapkan tingkat kebingungan tentang terminologi ramah lingkungan yangdigunakan oleh pemasar untuk menyampaikan "pesan ramah lingkungan" (Caswell dan Mojduszka 1996). Tujuan utama pelabelan lingkungan adalah untuk membantu pelanggan membuat pilihan produk yang diinformasikan. Namun, peninjauan dan evaluasi pasar ramah lingkungan menunjukkan bahwa beberapa pelanggan tampaknya tidak mampu memahami makna secara benar dari beberapa informasi pada label produk. Sebagai contoh, sebuah label didaur ulang, apakah hal ini menyiratkan bahwa produk dan/atau kemasan adalah 100 persen dapat didaur ulang? Menurut sebuah studi Wast (1995) ditemukan bahwa klaim dari atribut produk yang aman lingkungan seperti "eco-friendly","lingkungan aman", "dapat didaur ulang" "biodegradable" dan "ramah ozon" tidak dapat sepenuhnya diterapkan untuk produk.

Risikoketidaksamaan antara janji-janji promosi dan kenyataannya dianggap memiliki pengaruh negatif terhadap keputusan pembelian pelanggan (Harridge dan March 2006). Dalam sebuah survei 83 persen dari responden menunjukkan bahwa mereka lebih suka membeli produk yang aman lingkungan dan hanya 15 persen menunjukkan bahwa klaim lingkungan yang dapat dipercaya (Dagnoli 1991). Akhirnya, pelanggan enggan untuk membeli karena informasi asimetripenjual melekat dalam produk ketika melakukan transaksi (Gregg dan Walczak 2008).

Dalam beberapa kasus, konsumen tidak menyadari peraturan tentang keamanan lingkungan atau implikasi yang memungkinkan perusahaan untuk menempatkan label pada produk mereka (Iyer 1999). Hal ini barangkali menjadi faktor yang berkontribusi membuat pelanggan pada umumnya mengalami kebingungan terhadap klaim keamanan produk. Beberapa peneliti menemukan bahwa konsumen mempunyai masalah memahami informasi yang diberikan pada label produk. Sebagai contoh, kekhawatiran yang keliru tentang atribut produk lingkungan misalnya informasi yang diberikan tidak sedang, transparan, jujur, diskriminatifatau berdasarkan suara dan didukung bukti ilmiah. Bahkan kadangkadang menyesatkan (Polonsky et al., 1998). Dapat dikatakan bahwa pelanggan bisa bersikap skeptis tentang klaim produk dipertanyakan hasil dari beberapa tidak memadai, tidak akurat dan bahkan sulit untuk memahami informasi yang diberikan pada label produk. Mengingat bahwa konsumen tidak melihat dan menggunakan label produk sebagai sumber informasi, apakah persepsi pelanggan terhadap label 
ramah lingkungan dan jenis informasi yang membantu mereka untuk membuat keputusan pembelian informasi mempengaruhi niat membeli? Penelitian ini bertujuanuntuk menguji hipotesis berikut.

H1: Faktor citra perusahaan, label produk, persepsi peraturandan persepsi produk mempengaruhi persepsi responden secara keseluruhan terhadap produk ramah lingkungan dengan tingkat kekuatan dan kontribusi yang berbeda.

H2: Persepsi pelanggan secara keseluruhan tentang produk ramah lingkungan berpengaruh secara signifikan terhadap niat mereka untuk membeli produk ramah lingkungan, meskipun sedikit lebih mahal dan lebih rendah kualitasnya

\section{METODA PENELITIAN}

Hasil survey di lapangan melalui penyebaran kuesioner sejumlah 300 buah di tiga kota (Jogyakarta, Solo dan Semarang) berhasil mendapatkan 293 orang responden yang bersedia berpartisipasi. Responden yang dipilih yaitu para pembeli utama makanan rumah tangga di supermarket/mall yang tidak mempertimbangkan jenis kelamin mereka. Dianggap bahwa orang yang berbelanja di supermarket akan mewakili persepsi seluruh anggota keluarga tentang produk ramah lingkungan dalam perilaku pembelian mereka. Hasil ini yang dapat diolah kuesionernya sebanyak 258 responden (88 persen), sedangkan sisanya 35 kuesioner (12 persen) tidak dipakai karena banyak butir pertanyaan yang tidak dijawab (kosong).Jumlah responden 58 persen pria dan 42 persen wanita.Jumlah responden terbanyak adalah yang berusia 30 sampai dengan 40 tahun (61 persen).

Instrumen penelitian yang digunakan dalam penelitian ini disusun berdasarkan riset kualitatif dan kajian literatur sebelumnya (D’Sauza 2006). Instrumen penelitian kemudian dilakukan pra-uji dan dimodifikasi. Untuk menyertakan variabel yang memberikan kontribusi bagi pengolahan informasi pelanggan pada dimensi yang berbeda memberikan kontribusi bagi pembentukan persepsi secara komprehensif tentang produk ramah lingkungan.

Beberapa variabel penelitian pada tahun kedua ini adalah sebagai berikut.

1. Variabeldependen: keputusan pembelian produk ramah lingkungan meskipun sedikit lebih mahal atau kualitas lebih rendah.

2. Variabel independen: persepsi konsumen terhadap produk hijau.

3. Variabel eksogenous pada persepsi konsumen terhadap produk hijau: persepsi citra perusahaan, kepatuhan peraturan perusahaan dan label produk.

Semua pengukuran variabel tersebut dilakukan secara subyektif oleh para responden dengan menggunakan lima poin skala Likert (Wrenn 1997). Data 
dianalisis dengan menggunakan pengukuran deskriptif dan eksplorasi analisis faktor untuk mengidentifikasi dan memvalidasi kontribusi setiap butir pertanyaan untuk setiap komponen dalam model. Semua faktor diuji untuk construct validity and internal reliability mereka. Pemodelan struktural menggunakan Analisis of Moment Structures(AMOS) untuk menguji persepsi responden secara keseluruhan tentang produk ramah lingkungan dan niat mereka untuk membeli.

a. Uji Validitas

Hasil analisis faktor ditunjukkan pada Tabel 1.

Tabel 1

Matriks Analisis Faktor dengan Komponen Rotasi Varimax

\begin{tabular}{lrrrrr}
\hline & \multicolumn{5}{c}{ Component } \\
& 1 & 2 & 3 & \multicolumn{1}{c}{4} & \multicolumn{1}{c}{5} \\
\hline Labels1 & 0,146 & 0,918 & 0,053 & 0,040 & $-0,047$ \\
Labels2 & 0,106 & 0,889 & 0,097 & 0,117 & $-0,102$ \\
Labels3 & 0,197 & 0,918 & 0,030 & 0,074 & 0,036 \\
Label4 & 0,171 & 0,920 & 0,000 & 0,058 & 0,030 \\
CorImage1 & 0,074 & 0,051 & 0,729 & 0,216 & $-0,028$ \\
CorImage2 & 0,079 & 0,041 & 0,823 & 0,113 & $-0,054$ \\
CorImage3 & 0,116 & 0,052 & 0,854 & 0,031 & 0,144 \\
CorImage4 & 0,131 & 0,016 & 0,846 & 0,092 & $-0,016$ \\
ProductPercept1 & 0,829 & 0,164 & 0,107 & 0,059 & $-0,047$ \\
Productpercept2 & 0,741 & 0,161 & 0,238 & 0,040 & $-0,110$ \\
Productpercept3 & 0,879 & 0,155 & 0,043 & $-0,057$ & 0,100 \\
Productpercep4 & 0,852 & 0,136 & $-0,035$ & $-0,202$ & 0,041 \\
Productpercept5 & 0,729 & 0,059 & 0,149 & $-0,242$ & $-0,055$ \\
Packaging1 & $-0,179$ & 0,070 & 0,061 & 0,693 & $-0,106$ \\
Packaging2 & $-0,062$ & 0,049 & 0,213 & 0,822 & 0,079 \\
Packaging3 & $-0,039$ & 0,129 & 0,157 & 0,892 & 0,044 \\
GreenProdPercpt1 & 0,115 & $-0,043$ & $-0,021$ & 0,029 & 0,781 \\
GreenProdPecpt2 & $-0,165$ & $-0,011$ & 0,051 & $-0,026$ & 0,772 \\
\hline
\end{tabular}

Sumber: data diolah

Tabel 1 menunjukkan hasil analisis faktor dengan metodaprincipal component analysis mengesktraksi variabel manifest menjadi lima faktor berdasarkan eugin value. Tingkat persentasi kumulatif kontribusi seluruh faktor variabel penelitian sebesar 73,495 persen. Pemberian nama masing-masing faktor sebelumnya sudah ditentukan terlebih dahulu mengingat tujuan analisis faktor untuk penelitian ini adalah untuk meyakinkan apakah butir-butir pertanyaan yang diajukan benar-benar mewakili konstruk variabel yang diinginkan.

b. Reliabilitas

Koefisien kehandalan ditunjukkan oleh koefisien alpha Conback yang berkisar antara nol sampai dengan satu. Hasil pengujian reliabilitas dapat dilihat pada Tabel 2. 
Tabel 2

Hasil Uji Reliabilitas Pengukuran Variabel Penelitian

\begin{tabular}{lc}
\hline \multicolumn{1}{c}{ Variabel yang diukur } & Koefisien Alpha Cronback \\
\hline Corporate Image & 0,838 \\
Labeling & 0,961 \\
Product Perceptions & 0,886 \\
Green Product Perception & 0,740 \\
Regulatory & 0,787 \\
\hline Sumber: &
\end{tabular}

Berdasarkan Tabel 1 dan 2 dapat dijelaskan bahwa semua butir pertanyaan yang diajukan adalah valid dan reliabel.

\section{ANALISIS DATA DAN PEMBAHASAN}

Menjawab tujuan penelitian yang pertama, yakni merancang dan menguji model persepsi konsumen secara komprehensif terhadap produk ramah lingkungan, diperoleh hasil pengujian yang ditunjukkan pada Gambar 1. Hasil kriteria uji kecocokan model ditunjukkan pada Tabel 3 dan hasil estimasinya ditunjukkan pada Tabel 4.

Tabel 3

Evaluasi Model Hipotesis dengan Goodness of Fit Measures

\begin{tabular}{lcc}
\hline \multicolumn{1}{c}{ GOODNESS OF FIT } & CALCULATIONS OF & ACCEPTABILITY \\
\multicolumn{1}{c}{ MEASURES } & MEASURES & \\
\hline Chi-Square Test & 272,202 & moderate \\
Goodness of Fit Indeks & 0,891 & Accepted \\
Normed Fit Indeks & 0,909 & Accepted \\
Comparative Fit Indeks & 0,943 & Accepted \\
RMSEA & 0,076 & Accepted \\
\hline Sumber: data diolah & &
\end{tabular}

Sumber: data diolah

Tabel4

Hasil Estimasi Maximum Likelihood

\begin{tabular}{|c|c|c|c|c|}
\hline Regression Weights & Estimate & S.E & C.R & Keterangan \\
\hline $\begin{array}{l}\text { Regulatory } \rightarrow \\
\text { Perception }\end{array}$ & 0,293 & 0,075 & 3,897 & signifikan \\
\hline Labeling $\rightarrow$ Green Product Perception & 0,024 & 0,040 & 0,615 & Tidak signifikan \\
\hline $\begin{array}{l}\text { Corporate Image } \rightarrow \text { Green Product } \\
\text { Perception }\end{array}$ & 0,248 & 0,057 & 4,347 & signifikan \\
\hline $\begin{array}{l}\text { Product Perception } \rightarrow \text { Green Product } \\
\text { Perception }\end{array}$ & 0,192 & 0,064 & 3,005 & signifikan \\
\hline
\end{tabular}

Sumber: data diolah

Untuk menjawab pertanyaan penelitian sekaligus tujuan penelitian yang kedua menganalisis faktor-faktor (yaitu citra perusahaan yang ramah lingkungan, persepsi terhadap produk ramah lingkungan, label produk dan peraturan pemerintah) yang berpengaruh terhadap keputusan pembelian produk ramah lingkungan 
berdasarkan hasil rancangan dan pengujian pada model yang diusulkan (poin a), maka dari Gambar 1 dan Tabel 4 menunjukkan bahwa:

1. kontribusi perusahaan untuk membangun persepsi persepsi tentang produk hijau adalah positif dan signifikan $(r=0,248 ; p=0,000)$;

2. kontribusi peraturan perlindungan lingkunganuntuk membangun persepsi tentang produk hijau adalah positif dan signifikan ( $\mathrm{r}=0,294 ; \mathrm{p}=0,000)$;

3. kontribusi pemberian kemasan produk untuk membangun persepsi tentang produk ramah lingkungan tidak signifikan $(r=0,0248 ; p=0,539)$;

4. kontribusi persepsi produk produk untuk membangun persepsi tentang produk ramah lingkungan adalah negatif dan signifikan $(\mathrm{r}=-0,192 ; \mathrm{p}=0,003)$;

5. pengaruh persepsi tentang produk hijau pada niat pembelian bahkan jika produk ini agak lebih mahal $(\mathrm{r}=1 ; \mathrm{p}=0,01)$ adalah positif dan hal ini sama dengan pengaruh positif pada pembelian meskipun produk dari agak kualitas lebih rendah.

Untuk menjawab tujuan penelitian yang ketiga mengidentifikasi faktor terpenting yang dianggap oleh konsumen melalui pengujian model secara komprehensif, sehingga dapat memberikan bukti empiris untuk kepentingan implementasi strategi pemasaran berwawasan lingkungan Tabel 4menunjukkan bahwa reputasi perusahaan itu sendiri dan bagaimana sepak terjang dan promosi mereka dalam memperkenalkan produk adalah hal yang terpenting yang dapat membangun persepsi masyarakat terhadap produk ramah lingkungan.

Hasil studi ini dapat membuktikan bahwa sebenarnya pada masyarakat sudah tampak kesadaran pentingnya melestarikan lingkungan sehingga mereka sudah mulai berfikir untuk mengkonsumsi produk hijau. Faktor terbesar yang dapat membentuk persepsi produk ramah lingkungan ini adalah pada usaha-usaha yang dilakukan oleh perusahaan itu sendiri. Hal ini berarti tanggung jawab itu diasumsikan lebih banyak untuk perusahaan dan pelanggan mengharapkan bahwa budaya perusahaan harus mengubah arah perlindungan lingkungan, bukan maksimalisasi laba meskipun perlu dana yang lebih banyak. Selain itu, masyarakat untuk mengharapkan pemerintah dapat mengadakan peraturan yang lebih ketat terhadap produsen dalam menjalankan operasinya sehingga dapat menjamin adanya perlindungan terhadap lingkungan.

Tabel 3 menunjukkan perhitungan criteria fit model hipotesis menghasilkan tingkat penerimaan yang baik. Dengan demikian hasil ini mengindikasikan bahwa model hipotesis yang diusulkan dapat secara optimal menjelaskan fenomena tingkat kesadaran masyarakat terhadap produk ramah lingkungan.

Tabel 4 menunjukkan bahwa hipotesis yang pertama adalah faktor citra perusahaan, label produk, persepsi peraturan dan persepsi produk mempengaruhi persepsi responden secara keseluruhan terhadap produk ramah lingkungan dengan tingkat kekuatan dan kontribusi yang berbeda, dapat diterima. Dengan catatan kontribusi pemberian label produk berpengaruh tidak signifikan. Sedangkan 
hipotesis yang kedua adalah persepsi pelanggan secara keseluruhan tentang produk ramah lingkungan berpengaruh secara signifikan terhadap niat mereka untuk membeli produk ramah lingkungan, meskipun sedikit lebih mahal dan lebih rendah kualitasnya. Hipotesis ini didukung mengingat kriteria kesesuaian (fit) dalam studi ini dalam kondisi yang baik (lihat Tabel 3).

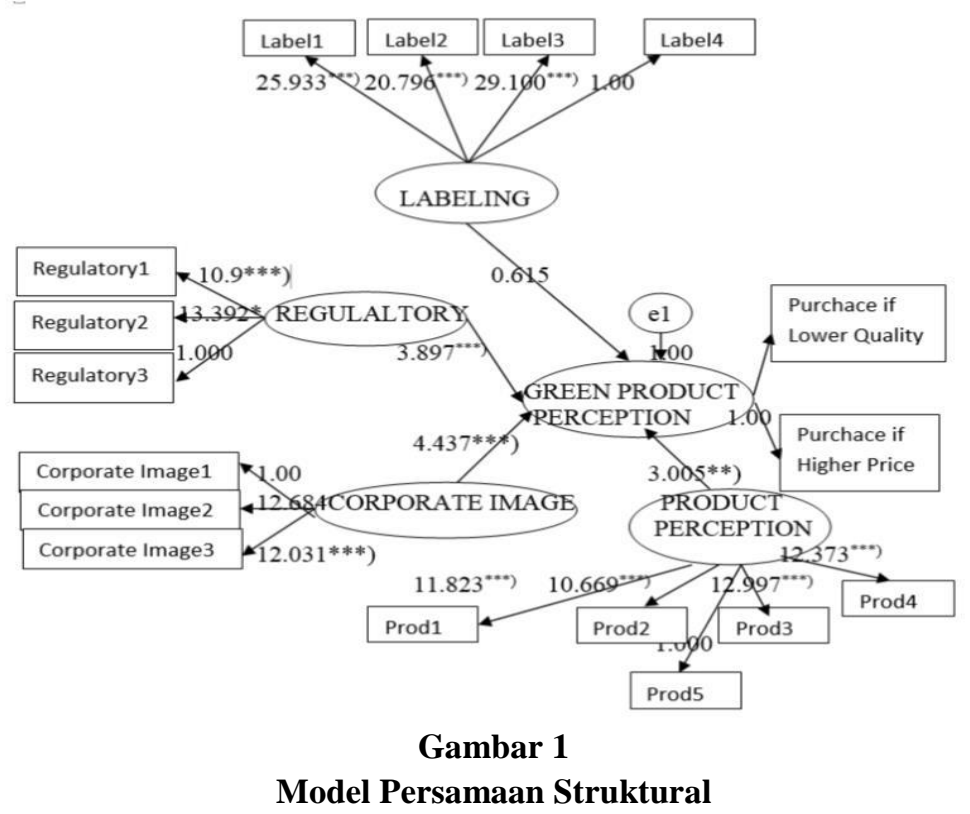

Model fit yang baik dalam studi ini menunjukkan perkembangan sikap masyarakat terhadap produk ramah lingkungan cukup baik. Bukti yang menyatakan bahwa persepsi keseluruhan produk hijau adalah negatif terkait dengan niat pelanggan untuk membeli kualitasnya lebih rendah dan harga yang lebih tinggi dibandingkan dengan produk-produk alternatif.Hasil studi ini menunjukkan ada harapan di bagian dari masyarakat bahwa semua produk yang ditawarkan harus aman lingkungan tanpa harus mengorbankan kualitas dan/atau harus membayar harga yang lebih tinggi untuk keistimewaan produk.

Masyarakat sangat mengharapkan pemerintah untuk dapat menjadi regulator yang baik, dengan produk regulasi yang dapat menjadi pengontrol perusahaan untuk dapat menghasilkan produk yang ramah lingkungan. Mereka akan merasa lebih yakin akan keamanan penggunaan sebuah produk apabila ada jaminan dari pemerintah.

Model persamaan struktural menunjukkan bahwa harapan terbesar untuk dapat membangun kesadaran masyarakat untuk memilih produk hijau adalah dari perusahaan itu sendiri. Usaha-usaha yang dilakukan perusahaan untuk pengelolaan limbah, kepedulian mereka terhadap lingkungan melalui media dan lain-lain, akan sangat membantu peningkatan kesadaran masyarakat untuk mengkonsumsi produk hijau. 
Kenyataan bahwa masih adanya sikap skeptik masyarakat terhadap produk ramah lingkungan dan pada saat yang sama, meskipun konsumen membaca label produk, mereka tampaknya tidak mempertimbangkan informasi yang diberikan pada label tersebut sepenuhnya akurat dan/atau mudah dipahami. Hal ini menunjukkan bahwa perubahan fundamental harus dilaksanakan dalam penawaran produk dan mengkomunikasikannya pada masyarakat. Bahwa memakai produk ramah lingkungan itu manfaatnya akan kembali pada pemakai sendiri. Daya tarik pasar produk hijau secara substansial tidak akan berubah kecuali adanya apabila sudah berjalan pergeseran persepsi secara dramatis.

\section{SIMPULAN DAN SARAN}

\section{Simpulan}

Sebagai simpulan, hasil studi ini mengungkapkan hal sebagai berikut.

a. Model penelitian yang diusulkan dalam penelitian ini dapat mewakili gambaran secara komprehensif persepsi masyarakat terhadap persepsi produk ramah lingkungan.

b. Variabel regulatory, corporate imagedan product perceptions berpengaruh secara signifikan untuk membentuk persepsi masyarakat pada produk ramah lingkungan.

c. Variabel corporate image adalah unsur terpenting dalam membentuk persepsi masyarakat terhadap produk ramah lingkungan.

\section{Saran}

Sebelum memberikan beberapa saran sebagai rekomendasi penelitian yang akan datang dan implikasi manajerial, beberapa keterbatasan yang perlu diperbaiki dalam penelitian ini antara lain sebagai berikut.

1. Studi yang dilakukan memiliki dimensi cross-sectional, sehingga pola hubungan yang diteliti merupakan protret sesaat yang menggambarkan hubungan-hubungan yang terjadi saat pengambilan data.

2. Model kurang mempertimbangkan variabel sikap dan perilaku konsumen yang menunjukkan tingkat kesadaran mereka terhadap lingkungan.

Sebaiknya penelitian yang akan datang dilakukan dengan metodatime series untuk mengetahui stabilitas tingkat kesadaran masyarakat terhadap lingkungan. Sehingga semua jawaban yang diberikan responden bukan merupakan emosi sesaat tetapi merupakan sikap dan perilaku sesungguhnya mereka terhadap lingkungan. Dalam menyusun strategi pemasaran perusahaan maka perusahaan tidak akan meninggalkan pertimbangan bagaimana sikap, perilaku dan karakteristik pasar mereka. Dengan memasukkan variabel ini model strategi pemasaran akan lebih komprehensif dengan mempertimbangkan dua sisi. 


\section{Implikasi manajerial}

Hasil analisis model penelitian menunjukkan munculnya harapan dari masyarakat agar perusahaan sendiri yang punya tanggung jawab lebih kuat daripada pemaksaan kontrol oleh pemerintah. Pada saat yang sama, masyarakat sudah mulai tumbuh kesadaran untuk mengkonsumsi produk ramah lingkungan dengan syarat tanpa mengurangi kualitas produk atau menetapkan harga yang lebih mahal daripada produk sejenis.

Adanya usaha pembentukan persepsi keseluruhan tentang produk hijau dari pihak perusahaan dengan menyediakan fasilitas untuk mengidentifikasi dan menerapkan strategi yang lebih mempengaruhi perubahan sikap oleh pelanggan. Usaha ini dapat meningkatkan kesadaran lingkungan dan perubahan sikap ini secara tidak langsung dapat mengakibatkan meningkatkan pilihan pangsa pasar.

Perusahaan juga dapat memperoleh manfaat dari identifikasi jenis-jenis informasi yang diperlukan untuk memungkinkan manajemen mempengaruhi proses pembentukan persepsi. Misalnya, jenis informasi yang akan diberikan kepada pelanggan dan metoda presentasi yang kredibel dan dapat meyakinkan kepada pelanggan untuk membeli produk yang ramah lingkungan dapat membantu proses keputusan pembelian pelanggan terhadap produk ramah lingkungan.

Label produk tidak menunjukkan mengkomunikasikan secara efektif informasi tentang keamanan produk. Jenis dan format informasi yang diberikan akan perlu dipahami oleh pelanggan jika hal itu akan menguntungkan mereka dalam pemilihan produk. Sebaiknya perusahaan menghindari penggunaan kode kimia dan istilah yang berkaitan dengan lingkungan keamanan produk yang tidak mudah dipahami konsumen secara umum. Akan lebih baik jika menggunakan bahasa yang umum tentang manfaat dan keuntungan mengkonsumsi produk ramah lingkungan.

\section{DAFTAR PUSTAKA}

Adcock, D. 2000.Marketing Strategies for Competitive Advantage. Chichester: Wiley: 132.

Arora, S.,dan T. Cason. 1996. Why do firms volunteer to exceed environmental regulations? Understanding participation in EPA's 33/50 program. Land Economics. Vol.72 No.4: 413-412.

Bennett, S. 1992. Green commitment: fading out? Progressive Grocer. Vol.71 No.12: 4-7.

Berger, I. 1993. The relationship between environmental attitudes and behavior.Canadian Journal ofMarketingResearch.Vol.12: 36-43. 
Berry, M.,danD. Rondinelli. 1998. Proactive corporate environment management: A new industrial revolution.The Academy ofManagement Executive. Vol.12 No.2: 38-51.

Bonini, S. M., J.G. Hintz, danL. T. Mendonca. 2008. Addressing consumer concerns aboutclimate change. McKinsey Quarterly.

Carlson, L., S. Grove, dan N. Kangun. 1993. A content analysis of environmental advertising claims: A matrix method approach.Journal of Advertising, Vol.22 No.3: 27-40.

Caswell, J., dan E. Mojduszka. 1996. Using informational informasi labelling to influence the market for quality in food products, food marketingpolicy center. University of Connecticut. Storrs, CT.

Chan, R. Y. 2001. Determinants of chinese consumers-green purchase behavior. Psychology \&Marketing. Vol.18 No.4: 389-413.

Chen, Y. S.,dan H. H. Chang. 2012. Enhance green purchase intentions the roles of green perceived value, green perceived risk, and green trust.Management Decision. Vol.50 No.3: 502-520.

Chase, D., dan T. K. Smith. 1992. Consumers keen on green but marketers don't deliver.Advertising Age(June): 63.

Dagnoli, J. 1991. Consciously green. Advertising Age.Vol.14: 41.

D'Souza,C., M. Taghian., P. Lam, dan R. Peretiatkos. 2006.The European Marketing Academy. Vol.1: 287-301.

Drumwright, M. 1994. Socially responsible organizational buying: Environmental concern as a noneconomic buying criterion. Journal of Marketing. Vol.58: 119.

Dwyer, R.J. 2009. Keen to be green organizations: A focused rules approach to accountability. Management Decision. Vol.47 No.7: 12-16.

Eid, M.I. 2011. Determinants of e-commerce customer satisfaction, trust, and loyalty in SaudiArabia.Journal of Electronic Commerce Research. Vol.12 No.1: 7893.

Elkington, J. 1989. Why it pays to be green.Weekend Financial Times (October):13.

Feldwick, P. 1996. What is brand equity anyway?.Journal of the Market Research Society. Vol.38 No.2: 85-104.

Fitzgerald, K. 1993. It's green, it's friendly, it's wal-mart, eco-store.Advertising Age. Vol.1: 44. 
Forte, M.,danB. Lamont. 1998. The bottom-line effect of greening (implications of ecological awareness).The Academy of Management Executive. Vol.12 No.1: 89-91.

Goll,I., N. B. Johnson, dan A. A. Rasheed. 2007. Knowledge capability, strategic change, and firm performance the moderating role ofthe environment.Management Decision. Vol.45 No.2: 161-179.

Gregg, D.G.,dan S. Walczak. 2008. Dressing your online auction business for success: An experiment comparing two e-Bay businesse.MIS Quarterly. Vol.32 No.3: 653-670.

Henion, K. 1972. The effect of ecologically relevant information on detergent sales. Journal of Marketing Research. Vol.9: 10-14.

Ippolito, P. M.,dan A. D. Mathios. 1990. Information, advertising and health choices: A study of the cereal market.Journal of Economics.Vol.21 No.3: 459-80.

Ippolito, P. M., dan A. D. Mathios. 1994. Information, policy and the source of fat and cholesterol in the US diet.Journal of Public Policy andMarketing. Vol.13 No.2: 200-217.

Iyer, G. 1999. Business, consumers and sustainable living in an interconnected world: A multilateral ecocentric approach.Journal of Business Ethics. Vol.20 No.4: 273-288.

Jensen, H., dan T. Kesavan. 1993. Sources of information, consumer attitudes on nutrition and consumption of dairy products. The Journal of Consumer Affairs. Vol.27 No.2: 352-372.

Levy, A. S., dan R. C. Strokes. 1987. Effects of a health promotion advertising campaign on sales of ready-to-eat cereal.Public Health Reports. Vol.102 No.4: 398-403.

Lee, J., D. H. Park, dan I. Han. 2011. The different effects of online consumer reviews on consumers' purchase intentions depending on trust in online shopping malls: An advertising perspective.Internet Research. Vol.21 No.2: 187-206.

Lyon, T. 2003. Green' firms bearing gifts.Regulation Washington. Vol.26 No.3: 36.

Mandese, J. 1991. New study finds green confusion.Advertising Age. Vol.62 No.45: $1-56$.

McGougall, G. 1993. The green movement in Canada: Implications for marketing strategy.Journal ofInternational Consumer Marketing. Vol.5 No.3: 69-87.

Ozmen, F. 2006. The level of preparedness of the schools for disasters from the aspect of the school principals. Disaster Prevention and Management. Vol.15 No.3: 383-395. 
Porter, M.,danC. V. Linde. 1995. Green and competitive: Ending the stalemate. Harvard Business Review. Vol.73 No.5: 120-134.

Rugman, A., dan A. Verbeke. 1998. Corporate strategies and environmental regulations: An organizing framework.Strategic Management Journal. Vol.19 No.4: 363-375.

Russo, M. V. R.,dan P. Fouts. 1997. A resource-based perspective on corporate environmental performance and profitability. Academy of Management Journal. Vol.40 No.3: 534-559.

Schwartz, J., dan T. Miller. 1991. The earth's best friends.American Demographics. Vol.13: 26-35.

Waskito, J., dan M. Harsono. 2012. Pengembangan dan implementasi model strategi pemasaran berwawasan lingkungan: Studi empiris pada masyarakat joglosemar.JDM. Vol.1: 33-39.

Wrenn, B. 1997. The market orientation construct: measurement and scaling issues.Journal of Marketing Theory. Vol.5 No.3: 31-54. 